\title{
High Carriage of Plasmid-Mediated Quinolone Resistance (PMQR) Genes by Cefotaxime-Resistant Escherichia Coli Recovered from Surface-Leaking Sanitary Sewers
}

\section{Abimbola Olumide Adekanmbi ( $\sim$ bimboleen@yahoo.com )}

Environmental Microbiology and Biotechnology Laboratory, Department of Microbiology, University of Ibadan, Nigeria. https://orcid.org/0000-0002-2871-1002

\section{Olabisi C. Akinlabi}

University of Ibadan

Adedolapo V. Olaposi

University of Ibadan

\section{Research Article}

Keywords: Cefotaxime-resistant bacteria, Escherichia coli, Sewage, Sanitary sewers, Antibiotic resistance, Plasmid-mediated quinolone resistance

Posted Date: July 15th, 2021

DOl: https://doi.org/10.21203/rs.3.rs-699642/v1

License: (c) (1) This work is licensed under a Creative Commons Attribution 4.0 International License. Read Full License

Version of Record: A version of this preprint was published at Archives of Microbiology on January 9th, 2022. See the published version at https://doi.org/10.1007/s00203-021-02627-6. 


\section{Abstract}

There is a rapid rise in the incident of quinolone resistant bacteria in Nigeria. Most studies in Nigeria have focused on isolates from the clinical settings, with few focusing on isolates of environmental origin. This study aimed to investigate the antibiogram and carriage of plasmid-mediated quinolone resistance (PMQR) genes by quinolone-resistant isolates obtained from a pool of cefotaxime-resistant Escherichia coli (E. coli) recovered from sewage leaking out of some broken sanitary sewers in a University community in Nigeria. Isolation of $E$. coli from the sewage samples was done on CHROMagar E. coli after enrichment of the samples was done in Brain Heart Infusion amended with $6 \mu \mathrm{g} / \mathrm{mL}$ of cefotaxime. Identification of presumptive $E$. coli was done using molecular methods (detection of uidA gene), while susceptibility to antibiotics was carried out using disc-diffusion method. Detection of PMQR genes ( $q n$ rA, $q n r B$, $q n r S$, aac $\left(6^{\prime}\right)-I b-c r, q e p A$ and $o q x A B$ ) was done using primer-specific PCR. A total of 32 non-repetitive cefotaxime-resistant $E$. coli were obtained from the sewage, with 21 being quinolone-resistant. The quinolone-resistant isolates showed varying level of resistance to the tested antibiotics, with imipenem being the only exception with $0 \%$ resistance. The PMQR genes: aac $\left(6^{\prime}\right)-1 b-c r$, qnrA, qnrB, qnrS and qepA and oqx $A B$ were detected in $90.5 \%, 61.9 \%, 47.6 \%, 38.1 \%, 4.8 \%$ and $0 \%$ respectively of the isolates. The findings of this study showed a high level of resistance to antibiotics and carriage of PMQR genes by quinolone-resistant $E$. coli obtained from the leaking sanitary sewers, suggesting a potential environmental and public health concern.

\section{Introduction}

The wastewater environment, specifically composed of high concentrations of bacteria, nutrients, and suspended solids is a known potential hub for the inception of antibiotic resistance and the stimulation of horizontal gene transfer [1]. The high levels of antibiotics typically discharged in human wastes into the environment, is known to sufficiently inhibit susceptible bacteria and provide a selective advantage to the resistant ones [2], making sewage and other wastewaters a favorable environment for bacterial growth and the likely spread of antibiotic resistance [3]. The typical end products (effluent or bio-solids), or non-typical routes like seepage through cracks in tanks, flooding or animal contact, and also aerosols, are channels by which bacteria in wastewater may enter the into the environment [4].

The use of quinolone antibiotics in human and veterinary medicine is on the rise due to their efficacy as important weapons against pathogenic bacteria via their ability to selectively inhibit the synthesis of DNA. These antibiotics constitute about $17 \%$ of the antibiotic global consumption [5], and are frequently encountered in domestic and hospital sewage because they are largely excreted unchanged in urine and faecal materials. [6]. Quinolones are not easily degraded, and are adsorbed to sewage sludge during biological treatment [7]. In a study carried out by Lindberg et al. [8] and Fink et al. [9], they found out that fluoroquinolones are hardly removed in effluent treatment plants, with approximately $70 \%$ remaining attached the sludge. In addition to this, the low effectiveness of treatment plants cannot be overlooked in the continuous spread of multidrug-resistant (MDR) bacteria into water aquifers [10]. 
The occurrence of quinolones in the environment has caused some substantial effects on the microbial structure and community, due to the exposure of these flora to the antibiotic at sub-lethal concentration, making them develop resistance to these agents. This eventually makes the environment a repository of antibiotic resistant bacteria carrying several resistance genes and other mobile genetic elements (MGE) $[11,12]$.

The detection of PMQR determinants in the late 1990s has opened the doors of research into the mechanisms of quinolone resistance in bacteria and their transferability. Different resistance mechanisms have so far been described and they range from the qnr gene families which encode proteins that protect DNA gyrase and topoisomerase IV from the destructive action of quinolones; aac( $\left.6^{\prime}\right)$ $\mathrm{Ib}$-crgene, coding for aminoglycoside acetyltransferase, which are involved in the acetylation of fluoroquinolones such as ciprofloxacin and norfloxacin; and two active efflux pumps, qepA and oqxAB, which confer decreased susceptibility to fluoroquinolones $[13,14]$.

Most data on quinolone resistance in Nigeria have focused majorly on the occurrence of these genes in clinical isolates, therefore making data related to the environment very few. This study therefore aimed at investigating the carriage of PMQR by Escherichia coli isolated from broken sanitary sewers within a University community.

\section{Materials And Methods}

\section{Study site and sample collection}

The study was carried out within the environment of an institution of higher learning in South-west Nigeria. Sanitary wastes from the students' hall of residence, staff quarters, other residential areas and the business pools are being channeled to a treatment plant via sanitary sewers located underground all across the University premises. A common challenge with this system of waste transportation is the breakage of conveying pipes as a result of several factors. This often times leads to the outflow of the content of the pipes into the environment, creating a very horrible sight and foul-smelling odour. Although this situation is remedied by the concerned unit of the University, it takes time before a positive action is taken on such breakage. The horrible sight of such breakage was a major motivating factor that stimulated the execution of this study. Sewage (SW) from the burst pipes were collected aseptically at different dripping points and transported to the laboratories on ice for microbiological analysis. Samples were analyzed about one hour after collection.

\section{Isolation of cefotaxime-resistant Escherichia coli from the samples}

Aliquot $(2 \mathrm{~mL})$ of each sewage sample was inoculated into $3 \mathrm{~mL}$ Brain Heart Infusion, to which a disc of $30 \mu \mathrm{g}$ cefotaxime ( $0 x$ oid, UK) has been added, giving a final concentration of $6 \mu \mathrm{g}$ of the antibiotic in the tube. The tubes were incubated overnight at $35 \pm 2^{\circ} \mathrm{C}$. Using the streak plate technique, a loopful of each of the cefotaxime-amended samples was inoculated onto the surface of already prepared CHROMagar $E$. 
coli (CHROMagar, France) and incubated for overnight at $35 \pm 2^{\circ} \mathrm{C}$. Blue colonies presumptive of Escherichia coli were picked, purified and stored in glycerol stock ( $15 \%$ glycerol).

\section{Molecular characterization of cefotaxime-resistant Escherichia coli}

The genomic DNA of presumptive Escherichia coli was extracted using the boiling lysis method according to the modified method of Gugliandolo et al. [15]. The identity of the isolates was confirmed by detecting the presence of uidA, a housekeeping gene in Escherichia coli. The method of Janezic et al. [16] was used for the PCR amplification of the gene. Escherichia coli OG1a possessing the uidA gene as reported by Adekanmbi et al. [17] was used as the positive control. Isolates possessing the uidA gene were selected for further studies. The details of the uidA primers are shown in Table 1.

\section{Susceptibility to antibiotics}

The confirmed Escherichia coli were subjected to a panel of eight antibiotics using the Kirby-Bauer disc diffusion method [20]. The procedure used for the testing, including the choice of medium, inoculum standardization, reading and interpretation of the zone diameter were as described by CLSI [21]. Isolates that were resistant to ciprofloxacin (a fluoroquinolone), were selected for the detection of the PMQR genes which encode quinolone resistance.

\section{Detection of PMQR genes}

The detection of six genes encoding PMQR in confirmed ciprofloxacin-resistant Escherichia coli was done using the methods of Wu et al. [18] and Park et al. [19]. The detection of qnrA, qnrB and qnrS and qepA was carried out using a duplex PCR, while a monoplex PCR was used for the detection of $\operatorname{aac}\left(6^{\prime}\right)-I b$ $c r$ and $o q x A B$. The PCR reaction volume was $25 \mu \mathrm{L}$ consisting of $5 \times$ PCR Master Mix (Jena Bioscience, Germany), forward and reverse primers $(0.25 \mu \mathrm{L}$ each, DNA template $(1 \mu \mathrm{L})$, with PCR quality water making up the volume. The oligonucleotide primers used in this study are highlighted in Table 1.

\section{Results}

Thirty-two non-repetitive cefotaxime-resistant Escherichia coli isolates were recovered from sewage obtained from the burst sanitary sewers. Twenty-one of the isolates representing $65.6 \%$ of the total isolates were resistant to ciprofloxacin (CIP), while 34.4\% (11/32) were sensitive to the antibiotic. The frequency of CIP-sensitive and CIP-resistant E. coli obtained in this study is shown in Figure 1.

The susceptibility of the isolates to eight antibiotics is highlighted in Table 2. There was varying level of resistance to the antimicrobials, with the only exception being imipenem, to which no resistance was observed. Six of the isolates (28.6\%) showed resistance to amoxicillin-clavulanate, seven (33.3\%) were resistant to ceftazidime, $10(47.6 \%)$ showed resistance to gentamicin and $19(90.5 \%)$ were resistant to trimethoprim/sulfamethoxazole. There was $100 \%$ resistance to each of cefotaxime, cefpodoxime and cefuroxime. 
Table 3 is showing the distribution of PMQR genes in the CIP-resistant Escherichia coli obtained from the sanitary sewer while Table 4 is showing the frequency of occurrence of the PMQR genes detected. All the targeted PMQR were detected in varying number of isolates, with the notable exception being oqxAB gene, which was not detected at all in any isolate. Of the six PMQR genes targeted for detection in this study, qnrA was detected in $13(61.9 \%)$ of the isolates, making it the second most prevalent PMQR gene, after $\operatorname{aac}\left(6^{\prime}\right)-1 b-c r$ (which was the most prevalent) with $19(90.5 \%)$ of the isolates harbouring it. The frequency of occurrence of qnrB, qnrS and qepA was $47.6 \%$ (10/21), 38.1\% (8/21) and 4.8\% (1/21) respectively. oqXAB was not detected in any of the twenty-one CIP-resistant Escherichia coli. One of the isolates (E. coliSWS2a), did not carry any of the six PMQR genes targeted, while six isolates carried one $P M Q R$ gene only. Four isolates carried two and three PMQR genes respectively, while four of the six PMQR genes were carried by 6/21 of the isolates. There was co-occurrence of PMQR genes in 14 (66.7\%) of the isolates.

\section{Discussion}

The fluoroquinolone antibiotics have been used extensively in the treatment of human and animal infections, mainly because of their selective inhibition of the synthesis of DNA in bacterial cells. These antibiotics also account for about $17 \%$ of the global use of antibiotics [5]. Ciprofloxacin, a secondgeneration fluoroquinolone has been widely used in the treatment of bacterial infections of human origin and is the one of the most abundant antibiotics detected in municipal biosolids, owing to their widespread use and the fact that it is excreted mostly unchanged in urine and faecal materials, making them available in high concentration in wastewater from hospitals and sewage $[5,6,22]$. The major difference between the quinolones of the first and second generation is the possession of a fluorine atom at sixth carbon of the quinolone moiety by the latter, and they exhibit a high level of potency against gram-negative bacteria and several gram-positive genera. In addition to this however, ciprofloxacin shows a high level of activity against Pseudomonas aeruginosa, making it a drug of choice in the treatment of a variety of infections $[23,24]$.

Resistance to fluoroquinolones has increased worldwide over the past few years and this has limited available treatment options, resulting in several cases of resistance and treatment failure [25-27]. The rising tide of antimicrobial resistance has been majorly linked to the widespread and continuous use of antibiotics in agriculture, human medicine and veterinary practices. This has placed a lot of selective pressure on bacteria, making it difficult to curtain the geometric rise in antibiotic resistance over the years [28-30]. Sewage and wastewater on the other hand have been taunted as ideal environment for the acquisition of antibiotic resistance genes (ARG) and this has been largely linked to influence from anthropogenic activities [31, 32].

In our study, a total of $21 \mathrm{CIP}$-resistant $E$. coli was obtained from the pool of 32 cefotaxime-resistant isolates recovered from the sanitary sewers. Bacteria showing resistance to quinolones, especially $E$. coli have been well reported in several studies. Osinska et al. [32] reported the isolation of FQRB from sewage and surface water samples in Poland, while studies carried out by Guillard et al. [33], Yang et al. [34] and 
Ranjbar et al. [35], pointed out the fact that Escherichia coli ranked as the most frequently occurring FQresistant bacteria from water, wastewater, animals, food and the clinical environment. A study carried out in Nigeria by Ehwarieme and his colleagues [36], reported the occurrence of FQ-resistant enteric bacteria from samples of human and animal origin, with Escherichia coli being the predominant organism obtained.

In this study, the target PMQR genes with the exception of oqxAB, were detected in twenty of the twentyone CIP-resistant isolates obtained, with one isolate devoid of any of the six PMQR genes. The qnr determinants, which have been reported to occur on chromosomal DNA in many environmental strains [37] are considered exclusively plasmid-borne in the Enterobacteriaceae [38]. These genes are proteins of the pentapeptide repeat family and are concerned with the protection of DNA gyrase and topoisomerase (IV) from the deleterious effect of the quinolone antibiotics. They are very diverse group of PMQR determinants and have been found resident in bacteria of animal, human and environmental origin. In this current study, three variants of the qnr gene were targeted with varying degree of detection observed in the CIP- resistant isolates. Of the qnr determinants, qnrA was the most prevalent in this study, with thirteen of the isolates $(61.9 \%)$ harbouring it, followed by $q n r B$ with 10 isolates $(47.6 \%)$ and $q n r S 8$ (38.1\%). The relative occurrence of the qnrgenes in this study is higher than the frequency of occurrence in a study carried out by Ranjbar et al. (2019), where they reported the detection of qnrA, qnrB and qnrS in $1 \%, 9 \%$ and $28 \%$ of the total isolates obtained from water sources in Iran, while a study on hospital wastewater in the same country by Ranjbar et al. [39], reported the detection of $q n r B$ and $q n r S$ in eleven $(45.8 \%)$ and seven $(29.2 \%)$ respectively of the $E$. coli isolates obtained. However, none of the isolates in their study harboured qnrA gene, which is contrary to this study.

The quinolone efflux pump ( $q e p A$ ) which was first described in a study by Yamane et al. [40], confers on the bacterial cell, the ability to reduce quinolone accumulation in the cell. It has been detected widely in many gram-negative genera in most countries of the world. In our study, one isolate (4.8\%) of the entire twenty-one CIP-resistant bacteria, harboured this particular gene. The low frequency of occurrence of the gene has been reported in several studies, and could be linked to its limited host spectrum. Chen et al. [41] reported a percentage occurrence of $2.6 \%$ for qepA in $1022 \mathrm{E}$. coli isolates obtained in their study, while Cattoir et al. [42] and Yamane et al. [43] detected qepA in $0.8 \%$ and $0.3 \%$ of the total isolates obtained in their respective studies.

There is limited data on oqxAB, an efflux pump-mediating gene, which was discovered in the late 2000 s. Its role as a PMQR was not identified until then, thereby making data available on the gene quite limited. It confers resistance to the veterinary growth-promoting quinoxaline-di- $N$-oxide olaquindox, and was first discovered in Escherichia coli from swine [44-46]. The frequency of occurrence of the gene in most studies is very low in comparism with other PMQR and this could explain the absence of the gene in all the quinolone-resistant isolates obtained in this study.

Aminoglycoside acetyltransferase $\left(\operatorname{aac}\left(6^{\prime}\right)-I b-c r\right)$ acts by causing the acetylation of quinolones, causing the modification of the antibiotics, which eventually leads to its inactivation. On its own, the resistance 
conferred on bacteria by aminoglycoside acetyltransferase is typically low, but it becomes elevated with the presence of qnrgene in the cell. In most reports on quinolone resistance in bacteria, $\operatorname{aac}\left(6^{\prime}\right)-\mathrm{lb}-\mathrm{cr}$ appears to be the commonest PMQR determinants [46-48], and this corroborates the observation in this study, where $90 \%(19 / 21)$ of the quinolone resistant bacteria carried the gene. This observation is in agreement with several other reports where the occurrence of the gene and its high prevalence in clinical samples and wastewater of hospital origin have been widely reported. In a study on hospital wastewater carried out by Chandran et al. [49], they detected $\operatorname{aac}\left(6^{\prime}\right)-I b-c r$ in $89 \%$ of their isolates, while Guillard et al. [33] and Piekarska et al. [27] detected the gene in $96.7 \%$ (118/122) and $85.7 \%$ of isolates obtained from samples and wastewater of clinical origin in their respective studies. In a different twist to the aforementioned, Su et al. [50] reported the detection of $\operatorname{aac}\left(6^{\prime}\right)-l b-c r$ in $5.1 \%$ of the total 452 quinoloneresistant isolates from a municipal treatment facility in China, making it the least occurring PMQR determinant in their study.

\section{Limitations Of The Study}

Despite the abundance of PMQR genes in the isolates obtained in this study, the limitations stem from the fact that the sampling process stopped as soon as the repair works on the burst sewers commenced, making it difficult to get more samples for the isolation of more resistant isolates. Despite this limitation, other studies could venture into the detection of PMQR in other bacterial genera and the genomic characterization of isolates obtained from such environment using advanced molecular biology tools. This will enrich the few available reports on PMQR in isolates of environmental origin.

\section{Conclusion}

This present study has provided some information on the occurrence of Escherichia colicarrying PMQR genes in sewage samples, with aac(6')-Ib-cr being the most predominant PMQR, while oqXAB was not detected in any of the isolates. There was different level of resistance shown to the tested antibiotics, with imipenem (a carbapenem) being the only antibiotic, to which resistance was not observed to. This suggests that the receiving environment of these untreated leaky wastewater is a potential repository of these resistant bacteria and PMQR genes, which could expose the University community to a potential public health challenge. This calls for a holistic approach to the concept of antibiotic resistance, which is majorly being looked at from the clinical perspective, as the environment is not spared of this menace. There is also a need for more proactive and urgent mechanisms to be put in place to address the issues of broken sewers within the community.

\section{Declarations}

\section{Funding}

The study was funded by the authors 
Acknowledgments

The authors would like to acknowledge the postgraduate students, who assisted with sample collection.

\section{Conflicts of interest/Competing interests}

No conflict of interest as regards this study.

\section{Availability of data and materials}

All the data generated or analysed during the execution of this study are included in this published article.

\section{Code availability}

Not applicable

\section{Authors' contributions}

Abimbola Olumide Adekanmbi developed the original idea and the protocol. All authors performed the experiments, and were involved in the collection of data collection. Abimbola Olumide Adekanmbi wrote the preliminary draft and analyzed the data. All authors read, revised and approved the manuscript for publication.

\section{Ethics approval}

Not applicable

\section{Consent to participate}

Not applicable

\section{Consent for publication}

All authors agreed to have this article published

\section{References}

1. Lorenz MG, Wackernagel W (1994) Bacterial gene transfer by Natural genetic Transformation in the environment. Microbiol Reviews 563-602

2. Kummerer K (2001) Introduction: Pharmaceuticals in the Environment. Pharma Environ Pp. 1-8

3. Mezrioui N, Baleux B (1994) Resistance patterns of E. coli strains isolated from domestic sewage before and after treatment in both aerobic lagoon and activated sludge. Water Res 28(11):23992406

4. Brandi G, Sisti M, Amagliani G (2000) Evaluation of the environmental impact of microbial aerosols generated by wastewater treatment plats utilizing different aeration systems. J Appl Microbiol 
88:845-852

5. Van Doorslaer X, Dewulf J, Van Langenhove H, Demeestere K (2014) Fluoroqunolone antibiotics: An emerging class of environmental micropollutants. Sci Total Environ 500-501:250-269

6. Kaplan E, Ofek M, Jurkevitch E, Cytryn1 E (2013) Characterization of fluoroquinolone resistance and qnr diversity in Enterobacteriaceae from municipal biosolids. Front Microbiol 4(144):1-7

7. Kümmerer K (2009) Antibiotics in the aquatic environment-a review-part l. Chemosphere 75:417434

8. Lindberg RH, Olofsson U, Rendahl PJ, Magnus I, Tysklind M, Andersson BAV (2006) Behavior of fluoroquinolones and trimethoprim during mechanical, chemical and active sludge treatment of sewage water and digestion of sludge. Envtl Sci Technol 40(3):1042-1048

9. Fink L, Dror I, Berkowitz B (2012) Enrofloxacin oxidative degradation facilities by metal oxide nanoparticles. Chemosphere 86:144-149

10. Korzeniewska E, Harnisz M (2013) Beta-lactamase producing Enterobacteriaceae in hospital effluents. J Environ Manag 123:1-7

11. Cordova-Kreylos AL, Scow K (2007) Effects of ciprofloxacin on salt marsh sediment microbial communities. The ISME J 1(7):585-595

12. Aminov RI (2009) The role of antibiotics and antibiotic resistance in nature. Environ Microbiol 11:2970-2978

13. Poirel L, Cattoir V, Nordmann P (2012) Plasmid-mediated quinolone resistance; interactions between human, animal, and environmental ecologies. Front Microbiol 3(24):1-7

14. Ruiz J, Pons MJ, Gomes C (2012) Transferable mechanisms of quinolone resistance. Int J Antimicrob Agents 40:196-203

15. Gugliandolo C, Lentini V, Spano A, Maugeri TL (2010) Conventional and molecular methods to detect bacterial pathogens in mussels. Lett Appl Microbiol 52:15-21

16. Janezic KJ, Ferry B, Hendricks EW, Janiga BA, Johnson T, Murphy S, Roberts ME, Scott SM, Theisen AN, Hung KF, Daniel SL (2013) Phenotypic and genotypic characterization of Escherichia coli isolated from untreated surface waters. Open Microbiol J 7:9-19

17. Adekanmbi AO, Adeleke OJ, Aremu OO, Olaposi AV (2020a) Molecular characterization, antibiogram and distribution of zntA gene in zinc-resistant Escherichia coli population recovered from anthropogenically-influenced surface water sources in Nigeria. Meta Gene 26:100789

18. Wu JJ, Ko WC, Tsai SH, Yan JJ (2007) Prevalence of plasmid-mediated quinolone resistance determinants QnrA, QnrB, and QnrS among clinical isolates of Enterobacter cloacae in a Taiwanese hospital. Antimicrob Agents Chemother 51(4):1223-1227

19. Park CH, Kim HB, Kim CJ, Kim EC, Jacoby GA, Hooper DC (2009) Prevalence of Plasmid-mediated Quinolone Resistance determinants over a 9-Year Period. Antimicrob Agents Chemother 53:639-645 20. Kirby-Bauer A (1996) Antimicrobial sensitivity testing by agar diffusion method. J Clin Pathol 44:493 
21. Clinical and Laboratory Standards Institute (CLSI) (2018) Performance Standards for Antimicrobial Susceptibility Testing 27th CLSI supplement M100 (Wayne: Clinical and Laboratory Standards Institute)

22. Xiong W, Sun Y, Ding X, Zhang Y, Zhong X, Liang W, Zeng Z (2015) Responses of plasmid-mediated quinolone resistance genes and bacterial taxa to (fluoro) quinolones-containing manure in arable soil. Chemosphere 119:473-478

23. Panton JH, Reeves DS (1988) Fluoroquinolone antibiotics. Microbiology, Pharmacokinetics and clinical use. Drugs 36(2):193-228

24. Van Bambeke F, Michot JM, Van Eldere J, Tulkens PM (2005) Quinolones in 2005:an update. Clin Microbiol Infect 11:256-280

25. Briales A, Rodrı́guez-Martı́nez JM, Velasco C, de Alba PD, Rodrı'guez-Ban o J, Martı́nez M et al (2012) Prevalence of plasmid-mediated quinolone resistance determinants qnr and aac (60)-lb-cr in Escherichia coli and Klebsiella pneumoniae producing extended-spectrum beta-lactamases in Spain. Int J Antimicrob Agents 39:431-434

26. Okade H, Nakagawa S, Sakagami T, Hisada H, Nomura N, Mitsuyama J, Yamagishi Y, Mikamo H (2014) Characterization of plasmid mediated quinolone resistance determinants in Klebsiella pneumoniae and Escherichia coli from Tokai. Japan J Infect Chemother 20:778-783

27. Piekarska K, Wołkowicz T, Zacharczuk K, Rzeczkowska M, Chróst A, Bareja E, Olak M, Gierczyński R (2015) Co-existence of plasmid mediated quinolone resistance determinants and mutations in gyrA and parC among fluoroquinolone- resistant clinical Enterobacteriaceae isolated in a tertiary hospital in Warsaw. Poland Int J Antimicrob Agents 45:238-243

28. Baquero F, Mart'ınez JL, Cant'on R (2008) Antibiotics and antibiotic resistance in water environments. Curr Opin Biotech 19:260-265

29. Harnisz M, Korzeniewska E, Gołaś I (2015) The impact of a freshwater fish farm on the community of tetracycline-resistant bacteria and the structure of tetracycline resistance genes in river water. Chemosphere 128:134-141

30. Kotlarska E, Łuczkiewicz A, Pisowacka M, Burzyński A (2015) Antibiotic resistance and prevalence of class 1 and 2 integrons in Escherichia coli isolated from two wastewater treatment plants, and their receiving waters (Gulf of Gdansk, Baltic Sea, Poland). Environ Sci Pollut Res 22:2018-2030

31. Marti E, Variatza E, Balcazar JL (2014) The role of aquatic ecosystems as reservoirs of antibiotic resistance. Trends Microbiol 22:36-41

32. Osińska A, Harnisz M, Korzeniewska E (2016) Prevalence of plasmid-mediated multidrug resistance determinants in fluoroquinolone-resistant bacteria isolated from sewage and surface water. Environ Sci Pollut Res 23:10818-10831

33. Guillard T, Bertrand X, de Champs C et al (2014) aac(6)-Ib-cr is the major plasmid-mediated quinolone resistance determinant in extended-spectrum $\beta$-lactamase-producing Escherichia coli in eastern France. J Glob Antimicrob Resist 2:111-113 
34. Yang HY, Nam YS, Lee HJ (2014) Prevalence of plasmid-mediated quinolone resistance genes among ciprofloxacin-nonsusceptible Escherichia coli and Klebsiella pneumoniae isolated from blood cultures in Korea. Cann J Infect Dis Med Microbiol 225:163-169

35. Ranjbar R, Tavanania S, Sabokbar A, Khamesipour F (2019) Prevalence and Characterization of Plasmid-mediated Quinolone Resistance Genes among Escherichia coli Strains Isolated from Different Water Sources in Alborz Province, Iran. The Indonesian Biomed J 11(1):36-41

36. Ehwarieme DA, Whiliki OO, Ejukonemu FE (2021) Occurrence of plasmid mediated fluoroquinolone resistance genes amongst enteric bacteria isolated from human and animal sources in Delta State, Nigeria. AlMS Microbiol 7(1):75-95

37. Poirel L, Van DL, Mammeri $\mathrm{H}$ et al (2005) Association of plasmid-mediated quinolone resistance with extended spectrum $\beta$-lactamase VEB-1. Antimicrob Agents Chemother 49:3091-3094

38. Rodriguez-Martinez JM, Cano ME, Velasco C, Martinez-Martinez L, Pascual A (2011) Plasmidmediated quinolone resistance: an update. J Infect Chemother 17:149-182

39. Ranjbar R, Masoudimanesh M, Dehkordi FS, Jonaidi-Jafari N, Rahimi E (2017) Shiga (Vero)-toxin producing Escherichia coli isolated from the hospital foods; virulence factors, o-serogroups and antimicrobial resistance proper-ties. Antimicrob Resist Infect Control 6:4

40. Yamane K, Wachino J, Suzuki S et al (2007) New plasmid mediated fluoroquinolone efflux pump, QepA, found in an Escherichia coli clinical isolate. Antimicrob Agents Chemother 51:3354-3360

41. Chen PL, Wu CJ, Chang CM et al (2007) Extra-intestinal focal infections in adults with Salmonella enterica serotype Choleraesuis bacteraemia. J Microbiol Immunol Infect 40:240-247

42. Cattoir V, Poirel L, Rotimi V, Soussy CJ, Nordmann P (2007) Multiplex PCR for detection of plasmidmediated quinolone resistance qnr genes in ESBL-producing Enterobacterial isolates. J Antimicrob Chemother 60:394-397

43. Yamane K, Wachino J, Suzuki S, Arakawa Y (2008) Plasmid-mediated qepA gene among Escherichia coli clinical isolates from Japan. Antimicrob Agents Chemother 52:1564-1566

44. Sørensen AH, Hansen LH, Johannesen E, Sørensen SJ (2003) Conjugative plasmid conferring resistance to olaquindox. Antimicrob Agents Chemother 47:798-799

45. Hansen LH, Johannesen E, Burmølle M, Sørensen AH, Sørensen SJ (2004) Plasmid-encoded multidrug efflux pump conferring resistance to olaquindox in Escherichia coli. Antimicrob Agents Chemother 48:3332-3337

46. Strahilevitz J, Jacoby GA, Hooper DC, Robicsek A (2009) Plasmid-mediated quinolone resistance: a multifaceted threat. Clin Microbiol Rev 22:664-689

47. Shaheen BW, Nayak R, Foley SL, Boothe D (2013) Chromosomal and plasmid-mediated fluoroquinolone resistance mechanisms among broad-spectrum-cephalosporin-resistant Escherichia coli isolates recovered from companion animals in the USA. J Antimicrob Chemother 68(5)

48. De Jong A, Muggeo A, El Garch F, Moyaert H, de Champs C, Guillard T (2018) Characterization of quinolone resistance mechanisms in Enterobacteriaceae isolated from companion animals in Europe (ComPath II study). Vet Microbiol 216:159-167 
49. Chandran SP, Diwan V, Tamhankar AJ, Joseph BV, Rosales-Klintz S, Mundayoor S, Lundborg CS, Macaden R (2014) Detection of car-bapenem resistance genes and cephalosporin, and quinolone resistance genes along with oqx-AB gene in Escherichia coli in hospital wastewater: a matter of concern. J Appl Microbiol 117(4):984-995

50. Su HC, Ying G, He L, Liu YS, Zhang RQ, Tao R (2013) Antibiotic resistance, plasmid-mediated quinolone resistance (PMQR) genes and ampC gene in two typical municipal wastewater treatment plants. Environ Sci: Processes Impact 16:324

\section{Tables}

Table 1: Oligonucleotide primers and amplicon sizes of PMQR genes targeted in this study

\begin{tabular}{|c|c|c|c|}
\hline Target gene & Primer sequence ( $5^{\prime}$ to $\left.3^{\prime}\right)$ & Amplicon size (bp) & Reference \\
\hline \multirow[t]{2}{*}{ qnrA } & TTCAGCAAGAGGATTTCTCA & 608 & [18] \\
\hline & GGCAGCACCATTACTCCCAA & & \\
\hline \multirow[t]{2}{*}{$q n r B$} & CCTGAGCGGCACTGAATTCAT & 389 & [18] \\
\hline & GTTTGCTGCTCGCCAGTCGA & & \\
\hline \multirow[t]{2}{*}{ qnrs } & CAATCATACATATCGGCACC & 621 & [18] \\
\hline & TCAGGATAAACAACAATACCC & & \\
\hline \multirow[t]{2}{*}{ qepA } & GCAGGTCCAGCAGCGGGTAG & 218 & [18] \\
\hline & СTTCCTGCCCGAAGTATCGTG & & \\
\hline \multirow[t]{2}{*}{$o q \times A B$} & CTCGGCGCGGATGATGCT & 392 & [18] \\
\hline & ССАСTCTTCACGGGAGACGA & & \\
\hline \multirow[t]{2}{*}{$\operatorname{aac}\left(6^{\prime}\right)-\mathrm{lb}-c r$} & TTGCGATGCTCTATGAGTGGCTA & 482 & [19] \\
\hline & CTCGAATGCTTGGCGCGTTT & & \\
\hline
\end{tabular}

Table 2: Resistance of the ciprofloxacin-resistant Escherichia coli to antibiotics ( $\mathrm{n}=21)$ 


\begin{tabular}{|c|c|c|c|}
\hline Antibiotics (Concentration) & Sensitivity (\%) & Intermediate (\%) & Resistance (\%) \\
\hline SXT $(25 \mu \mathrm{g})$ & $2(9.5)$ & $0(0)$ & $19(90.5)$ \\
\hline $\mathrm{CN}(15 \mu \mathrm{g})$ & $5(23.8)$ & $6(28.6)$ & $10(47.6)$ \\
\hline IPM $(5 \mu \mathrm{g})$ & $21(100)$ & $0(0)$ & $0(0)$ \\
\hline CTX $(30 \mu \mathrm{g})$ & $0(0)$ & $0(0)$ & $21(100)$ \\
\hline AMC $(30 \mu \mathrm{g})$ & $10(47.6)$ & $5(23.8)$ & $6(28.6)$ \\
\hline CPD $(30 \mu \mathrm{g})$ & $0(0)$ & $0(0)$ & $21(100)$ \\
\hline CAZ $(30 \mu \mathrm{g})$ & $8(30.1)$ & $6(28.6)$ & $7(33.3)$ \\
\hline 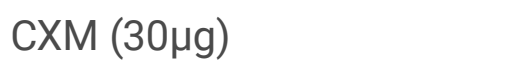 & $0(0)$ & $0(0)$ & $21(100)$ \\
\hline
\end{tabular}

KEY: $\mathbf{n}$ : Total number of ciprofloxacin-resistant bacteria obtained; SXT: trimethoprim/sulfamethoxazole $(25 \mu \mathrm{g}) \mathrm{CN}$ : gentamycin $(15 \mu \mathrm{g}) ;$ IMP: imipenem $(5 \mu \mathrm{g})$; CTX: cefotaxime $(30 \mu \mathrm{g}) ;$ CPD: cefpodoxime $(30 \mu \mathrm{g})$; AMC: amoxicillin-clavulanate $(30 \mu \mathrm{g})$; CAZ: ceftazidime $(30 \mu \mathrm{g})$; CXM: cefuroxime $(30 \mu \mathrm{g})$

Table 3: Distribution of PMQR genes in the ciprofloxacin-resistant Escherichia coli 


\begin{tabular}{|c|c|c|c|c|c|c|}
\hline Lab Code & qnrA & $q n r B$ & qnrS & $q e p A$ & $O q \times A B$ & $\operatorname{aac}\left(6^{\prime}\right)-1 b-c r$ \\
\hline SW1b & - & - & - & - & - & + \\
\hline SW1d & - & - & - & + & - & + \\
\hline sw2a & + & - & - & - & - & - \\
\hline SW2e & - & - & - & - & - & + \\
\hline sw3a & - & - & - & - & - & + \\
\hline sW3b & + & - & + & - & - & + \\
\hline sW3c & - & - & - & - & - & + \\
\hline SWS1b & - & - & - & - & - & + \\
\hline sWS1c & + & + & + & - & - & + \\
\hline SWS1d & - & + & + & - & - & + \\
\hline sWS1e & + & + & + & - & - & + \\
\hline sWS2a & - & - & - & - & - & - \\
\hline sWS2b & + & - & - & - & - & + \\
\hline SWS2c & + & + & + & - & - & + \\
\hline sWS2d & + & + & - & - & - & + \\
\hline sWS3a & + & + & + & - & - & + \\
\hline SWS3c & + & + & + & - & - & + \\
\hline SWS3d & + & + & + & - & - & + \\
\hline SWS4c & + & + & - & - & - & + \\
\hline SWS4d & + & + & - & - & - & + \\
\hline SWS4e & + & - & - & - & - & + \\
\hline
\end{tabular}

KEY: +: Target gene present; -: Target gene absent.

Table 4: Frequency of occurrence of PMQR genes in the ciprofloxacin-resistant Escherichia coli 


\begin{tabular}{|lll|}
\hline PMQR gene & Frequency & Percentage Occurrence (\%) \\
\hline qnrA & $13 / 21$ & 61.9 \\
\hline qnrB & $10 / 21$ & 47.6 \\
\hline$q n r S$ & $8 / 21$ & 38.1 \\
qepA & $1 / 21$ & 4.8 \\
oqXAB & $0 / 21$ & 0 \\
\hline $\operatorname{aac}\left(6^{\prime}\right)-I b-c r$ & $19 / 21$ & 90.5 \\
\hline & & \\
\hline
\end{tabular}

Figures

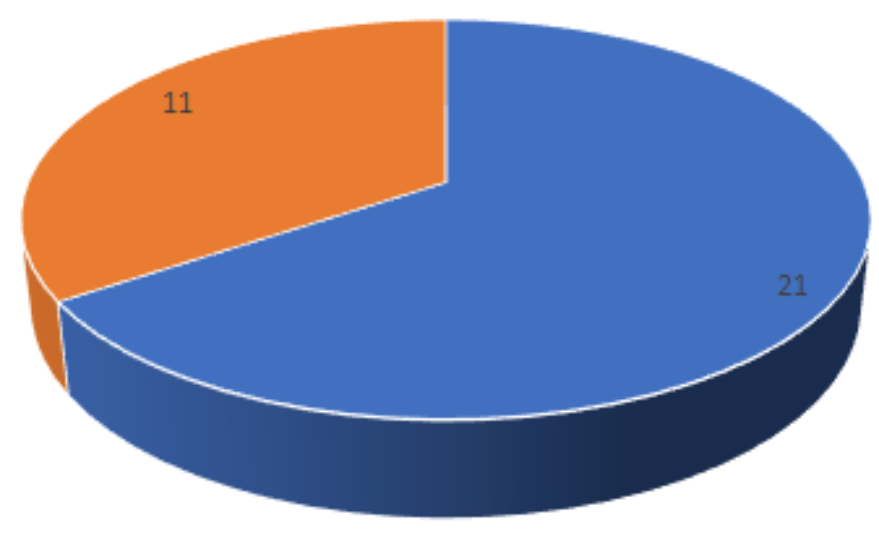

- CIP-resistant E. coli " CIP-sensitiv e E. coli

\section{Figure 1}

Frequency of CIP-sensitive and CIP-resistant E. coli isolated in this study 